\title{
Nonmetropolitan Industrial Expansion: Emerging Implications For Regional Development
}

\author{
Rodney A. ERICKSON*
}

Between 1960 and 1970, manufacturing employment increased by twenty-two percent in nonmetropolitan areas of the United States [16]. While a majority of new manufacturing employment continues to be created in metropolitan urban centers, the pace of industrial decentralization continues to quicken.

The recent employment growth trend in many heretofore declining nonmetropolitan communities has created optimism that public policies can be formulated and implemented which will accomplish greater economic balance over the spatial landscape. The following analysis examines the characteristics of recent industrial location and expansion in a case study of nonmetropolitan Wisconsin, using the "filtering-down" process as a conceptual framework. The results of the analysis are used to explore some impacts of continued industrial decentralization and suggest some directions for public policy.

\section{THE BASIS FOR NONMETROPOLITAN INDUSTRIAL EXPANSION}

The process of industrial decentralization has been characterized as a "filtering-down" phenomenon, based on the proposition that industries filter down through the system of urban places, from cities of greater to lesser industrial sophistication [18]. Industrial decentralization thus represents the spatial manifestation of changes which occur in production and industrial organization in accordance with the product life cycle [4].

Hirsch [10] has identified three phases of growth through which many products typically pass. The "gestation" or new product phase is characterized by a labor-intensive production function and a substantial engineering and technical input component. The necessity for technical and engineering inputs and the external economies often associated with such activities generally restricts the product developmental phase to larger urban areas. During the "growth" phase, the volume of product output increases rapidly. Managerial ability and growth capital are critical production factors which influence a firm's ability to compete during this intermediate phase of the product cycle. Skill/technical requirements

*Assistant Professor of Urban and Regional Planning, University of Wisconsin. 
begin to decline, especially in later stages of the growth phase as production processes become standardized and mechanized. The final or "mature" phase is characterized by its slow rate of growth in product output or absolute decline. The availability of entry or expansion capital and a pool of unskilled labor permits firms to produce efficiently and competitively in a tightening market.

Two aspects of the production factor characteristics in the product cycle concept are important in explaining nonmetropolitan industrial expansion. First, as an industry reaches the late growth or mature phase, the capability for innovations, external economies and the infrastructure to support that capability decline in relative importance. The abundance of low-cost, unskilled or semi-skilled labor in nonmetropolitan areas, many of which have experienced decades of employment depletion through mechanization of agriculture and resource-related activities, creates a strong attractive force for manufacturing industry. Second, the relative importance of managerial skills and capital in the late growth or mature phase suggests that corporate organizations (as opposed to indigenous establishments) have a greater probability of organizing the critical non-labor production factors. Corporations typically utilize branch plants to exploit large pools of unskilled and semi-skilled labor in nonmetropolitan areas.

In addition to the localization of new firms in nonmetropolitan areas, substantial manufacturing employment increases also occur as a result of expansion in existing enterprises. Expansions in productive capacity/ employment occur when management perceives opportunities to increase net revenues or achieve other related goals. Productive capacity expansions thus may be undertaken (1) to satisfy demand associated with growth in the product market $(\mathrm{s}) ;(2)$ to become more competitive on a unit cost basis; (3) to introduce a new product line; and (4) to achieve some combination of the above.

A number of economists have documented the direct relationship between firm growth and the process of innovation which is frequently embodied in new plant and equipment, giving rise to unit cost reductions $[13,14]$. Thus, the expansion of capacity related to greater efficiency and competitive position is an important indication of growth potential among a region's manufacturing establishments. However, if industrial decentralization and expansion are indeed characterized by firms operating in the late growth or mature phase of the product cycle, the expansion of nonmetropolitan manufacturing establishments is more likely a reflection of general market expansion.

The spatial distribution of localizing and expanding manufacturing enterprises is also of significance, given the geographic dimension of public policies to induce nonmetropolitan employment growth. Interest in the "growth center" concept has led to the suggestion that employment expansion, including manufacturing activities, is most likely to be enhanced in the largest nonmetropolitan urban centers. These centers generally possess more of the basic infrastructure, larger labor pools, external 
economies and amenities traditionally deemed to be of importance in manufacturing location and expansion decisions.

\section{EMPIRICAL ANALYSIS}

The following analysis examines recent manufacturing localization and expansion in a fifty-two county area of nonmetropolitan Wisconsin. ${ }^{i}$ Information concerning manufacturing localizations and expansions during the 1969-1974 period was provided by the State Department of Business Development. Sources of the data include unemployment compensation records, articles of incorporation, tax records, inspections for occupational safety and other governmental regulations, and reports from field representatives.

During the six-year study period, 202 manufacturing enterprises employing five or more workers located in the study area. These enterprises included 110 branch plants, eighty-four new indigenous firms, and eight enterprises relocated from outside Wisconsin. Branch plants were typically larger establishments, the average plant employing forty-six workers. In contrast, new indigenous enterprises employed an average of nineteen workers per firm as did relocations. Thus, branch plants accounted for seventy-six percent of new employment among the recorded localizations indicating a significant degree of corporate organizational activity in nonmetropolitan manufacturing localizations. In addition, 775 manufacturing enterprises undertook plant expansions which resulted in additional productive capacity.

\section{Survey Coverage and Industry Groups}

By 1975, 120 of the original 202 locating firms were found to be operating in their recorded locations. Knowledgeable representatives of firms were asked to identify their primary locational objectives, community attributes influencing the location decision, and important plant site features. The recent locational and site survey questionnaire utilized by the Department of Commerce [19] provided the basic questionnaire format. A total of 108 establishments cooperated in the survey. The survey coverage of various industry groupings is indicated in Table 1; it reflects closely the sectoral distribution of all recorded plant localizations. Nearly all of these manufacturing establishments produce standardized products, assemblies, components, or traditional resource transformations.

In addition, a ten percent random sample of those firms which had undergone plant expansions was taken. Knowledgeable representatives of firms were asked to identify the principal reason for their plant expansion. These reasons were categorized as (1) increased market demand; (2) increased market demand and new product lines; (3) enhanced efficiency through process change; (4) a combination of (1) and (3); and (5) government regulation. A total of sixty-two usable questionnaires was completed. The survey coverage of various industry groups is given in Table 1. 
TABLE 1

Survey Coverage of Major Manufacturing Groups Locating and

Expanding Establishments in Nonmetropolitan Wisconsin, 1969-1974

\begin{tabular}{llcc}
\hline \multicolumn{1}{c}{ SIC Group } & $\begin{array}{c}\text { Number of } \\
\text { Locating Firms }\end{array}$ & $\begin{array}{c}\text { Number of } \\
\text { Expanding Firms }\end{array}$ \\
\hline 20 & Food \& Kindred Products & 11 & 12 \\
23 & Apparel \& Related Products & 9 & 1 \\
24 & Lumber \& Wood Products & 17 & 8 \\
30 & Rubber \& Plastics Products & 5 & 6 \\
34 & Fabricated Metal Products & 21 & 8 \\
35 & Machinery \& Non-Electrical Equipment & 9 & 6 \\
36 & Electrical Equipment & 14 & 2 \\
39 & Miscellaneous Manufacturing & 5 & 3 \\
& Other & 21 & 16 \\
& Total Establishments & - & 62
\end{tabular}

\section{Locational Objectives}

Table 2 indicates that branch plant operations typically sought to locate in areas which would provide (1) assurance of an adequate pool of labor; (2) spatial proximity to other plants or headquarters of the corporation; and (3) proximity to distributors/customers. Such behavior is consistent with the "filtering-down" process of nonmetropolitan industrial location.

Many corporations utilized nonmetropolitan branch plant operations to produce assemblies or components for other corporate main plants;

\section{TABLE 2}

Primary Locational Objectives of Surveyed Manufacturing Enterprises Locating in Nonmetropolitan Wisconsin, 1969-1974

\begin{tabular}{lcr}
\hline \multicolumn{1}{c}{ Locational Objectives } & \multicolumn{2}{c}{ Number of Responses } \\
Branch Plant & New Firm \\
\hline Minimize transportation costs & 2 & 4 \\
Less urbanized location & 0 & 10 \\
More land for operation and expansion & 3 & 2 \\
Proximity to resources/suppliers & 8 & 6 \\
Proximity to other plants of the & 12 & 3 \\
$\quad$ company or historical ties & 10 & 6 \\
Proximity to distributors/customers & 1 & 0 \\
Proximity to other firms in the & 6 & 3 \\
$\quad$ same manufacturing activity & 19 & 2 \\
Access to new/expanded markets & 4 & 7 \\
Minimize competition for labor force & - & 43 \\
Unique factors/personal reasons & 65 & \\
Total Responses & &
\end{tabular}

Source: Adapted from [4]. 
thus proximity becomes an important factor for shipping and operations coordination. A majority of surveyed firms were headquartered in metropolitan centers of Wisconsin and other Midwestern states. Figure 1 depicts the location of main plants/headquarters of Midwestern manufacturing corporations which established branch plants in nonmetropolitan Wisconsin during the study period.

In contrast, indigenous new firms were more likely to prefer less urbanized locations in their own right and personal considerations ("other" category). A likelihood ratio test of differences in branch plant and new firm locational objectives indicates that these differences are significant at the .01 level $\left(\log _{\mathrm{e}} \lambda=-18.23\right.$ with 11 d.f. $) .{ }^{2}$ Inasmuch as branch plant localizations accounted for the predominant portion of new localized manufacturing employment, the importance of adequate labor pools and organizational and market proximity in nonmetropolitan industrial development is apparent.

\section{Community Attributes Attracting Firms}

Table 3 indicates several interesting variations in the responses of firms to different community attributes. In general there is a notable lack of

Figure 1. Location of Midwestern Headquarters/Main Plants of Manufacturing Corporations Establishing Branch Plants in the Study Region, 1969-1974

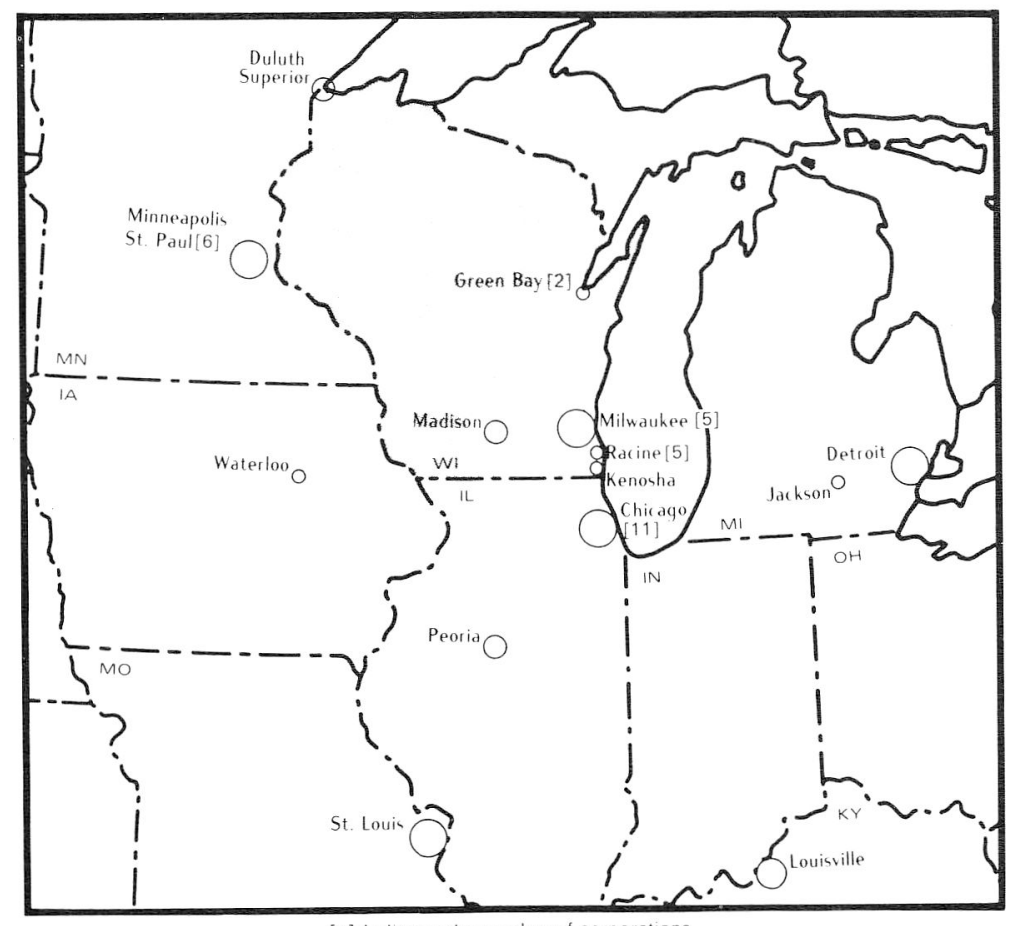

[n] Indicates the number of corporations 
TABLE 3

Principal Community Attributes Attracting Surveyed Manufacturing Enterprises Locating in Nonmetropolitan Wisconsin, 1969-1974

\begin{tabular}{|c|c|c|}
\hline \multirow[b]{2}{*}{ Community Attributes } & \multicolumn{2}{|c|}{ Number of Responses } \\
\hline & Branch Plant & New Firm \\
\hline Air passenger service & 0 & 1 \\
\hline Contract trucking & 1 & 0 \\
\hline Public warehousing & 0 & 0 \\
\hline Fire and police protection & 0 & 0 \\
\hline Local industrial development group & 7 & 6 \\
\hline Industrial revenue bond financing & 0 & 1 \\
\hline Tax incentives and holidays & 0 & 0 \\
\hline Vocational training & 1 & 0 \\
\hline Higher education facilities & 1 & 0 \\
\hline Pool of trained workers & 7 & 7 \\
\hline Pool of unskilled workers & 32 & 7 \\
\hline Small town environment & 3 & 9 \\
\hline Availlable building & 8 & 6 \\
\hline Other & 5 & 6 \\
\hline Total Responses & $\overline{65}$ & $\overline{43}$ \\
\hline
\end{tabular}

Source: Adapted from [4].

response to those attributes which could be labeled infrastructure and community services. While the study area is relatively well-served with airports and available contract trucking, the availability of these facilities/services was of little locational importance to either branch plants or new indigenous firms. Similarly, vocational training and higher education facilities which are spatially-dispersed for service delivery attracted few firms. The relatively greater level of response to available industrial shells suggests that firms locating in nonmetropolitan communities are more strongly influenced by the existence of suitable building facilities than by most traditional infrastructure elements.

While Wisconsin legislation permitting local industrial revenue bonding has been in existence since 1969, industrial revenue bonding does not appear to have been a primary attribute in attracting firms to particular communities, although many firms have utilized this method of plant financing. However, the aggressive role of local industrial development groups was attractive for many firms, and generally interpreted as an indication of a favorable "business climate". Tax incentives and holidays elicited no response from firms.

The predominant concern of branch plants with low-skill (and usually low-wage) labor pools is apparent from Table 3. While small differences are evidenced between branch plants and new firms in all attributes except "pool of unskilled labor" and "small town environment", these two attributes create a significant difference between groups. A likelihood ratio test of non-zero attributes indicates that these differences are significant at the .025 level $\left(\log _{\mathrm{e}} \lambda=-11.68\right.$ with 12 d.f. $)$. 


\section{Plant Site Features}

Table 4 indicates that approximately two-thirds of all locating firms chose plant sites because of one of two features: site size or highway access. Forty-eight firms indicated that room for subsequent expansion(s) was the overriding consideration; twenty-four firms indicated that suitable highway access for motor freight was the primary influence in their site selection process. Rail service was cited by only ten percent of respondent firms, thus reflecting the relatively footloose character of most localized manufacturing establishments which rely primarily upon motor freight as a transportation mode.

There appears to be little variation in the pattern of response to plant site features between branch plants and new indigenous firms. A likelihood ratio test of differences in non-zero attributes was not significant $\left(\log _{e} \lambda=-2.55\right.$ with 9 d.f.). However, it is to be expected that the nature of the product itself and the associated manufacturing and distribution processes are more significant than the form of legal organization in determining influential plant site features.

The data do not support the hypothesis that large-scale manufacturing localization is occurring in rural areas outside the municipal boundaries of villages and cities. Ninety-two of the 108 respondent firms were located within the city limits of their respective municipalities. ${ }^{3}$ Approximately half of the respondent firms were located in industrial parks.

\section{Plant Expansion Decisions}

During the six-year study period, recorded new manufacturing employment resulting from plant expansions was approximately double that resulting from the establishment of new manufacturing enterprises. Thus,

\section{TABLE 4}

Plant Site Features Influencing Location Decisions Among Surveyed Firms Locating in Nonmetropolitan Wisconsin, 1969-1974

\begin{tabular}{lcc}
\hline \multicolumn{1}{c}{ Plant Site Feature } & \multicolumn{2}{c}{ Number of Responses } \\
Highway Access & Branch Plants & New Firms \\
Air Freight & 15 & 9 \\
Water Transportation & 0 & 1 \\
Rail Service & 0 & 0 \\
Water Supply & 8 & 4 \\
Natural Gas & 0 & 1 \\
Solid Waste Disposal & 2 & 0 \\
Site Size & 0 & 0 \\
Building Features & 29 & 19 \\
Other & 6 & 7 \\
Total Responses & 5 & - \\
\hline
\end{tabular}

Source: Survey data 
although the latter frequently receive greater public attention, the expansion of capacity in existing plants was a significant employment growth factor in many of the nonmetropolitan communities.

Table 5 provides an indication of the principal reasons which led to plant expansion decisions in the region. Over two-thirds of respondent enterprises indicated that a general expansion in market demand for the industry had prompted their expansion decisions. Five additional firms indicated that increased market demand for products which they were incorporating into their production had prompted their expansion decision. Only seven firms reported that expansion was undertaken solely to achieve relative cost reductions in order to compete more effectively in their respective product markets. Five additional firms indicated that in the wake of expansions to meet higher levels of product demand, new production processes were incorporated which brought about greater efficiency.

These findings suggest that capacity expansion in the nonmetropolitan study area is primarily a function of growth in national or regional demand for products of the area. Manufacturing employment expansion has not been brought about by cost reductions in many plants.

\section{Distribution of Manufacturing Growth in Cities and Villages}

Within the study area manufacturing employment in cities and villages increased by over 25,000 workers during the 1970-1974 period. This growth was geographically dispersed among a large number of cities and villages in the region. Table 6 shows the average employment increases in manufacturing activity among four size classes of population centers for which the Wisconsin Department of Industry, Labor and Human Relations regularly compiles employment data. Table 6 indicates that larger urban centers of the region individually captured the largest net increments of manufacturing employment. Such centers have sufficient infrastructure to accommodate substantial employment increases and provide an adequate labor supply. Although small in average growth increment, villages (ranging in population from 144 to 3,445 persons)

TABLE 5

Reasons for Plant Expansion Decisions in Nonmetropolitan Wisconsin 1969-1974

Reason

Responses

(1) Increased market demand

(2) Increased market demand/new product line (s)

(3) Enhanced efficiency through process change

(4) Combination of (1) and (3)

(5) Meet government requirements

'Total Responses

62

Source: Survey data 
TABLE 6

Manufacturing Employment Growth in Cities and Villages of Nonmetropolitan Wisconsin By Size Class, 1970-1974

\begin{tabular}{lccc}
\hline $\begin{array}{c}\text { Population Center } \\
\text { Size Classification }\end{array}$ & $\begin{array}{c}\text { Average Net } \\
\text { Manufacturing } \\
\text { Employment Change } \\
\text { per Center }\end{array}$ & $\begin{array}{c}\text { Number } \\
\text { of } \\
\text { Centers }\end{array}$ & $\begin{array}{c}\text { Total Group } \\
\text { Manufacturing } \\
\text { Employment } \\
\text { Increase }\end{array}$ \\
\hline $\begin{array}{l}\text { Villages } \\
\text { Cities with }<5,000 \text { Population }\end{array}$ & +25 & 171 & $+4,224$ \\
Cities with 5,000 & +78 & 87 & $+6,751$ \\
to 20,000 Population & +477 & 21 & $+10,021$ \\
Cities with $>20,000$ Population & +1382 & 3 & $+4,146$ \\
\hline
\end{tabular}

11970 population counts

Source: Derived from Wisconsin State Department of Industry, Labor and Human Relations data.

showed an impressive employment turnaround. Despite the comparatively small average net manufacturing employment in villages, the large number of such population centers relative to the number of the largest urban places contributed to a total growth increment approximately equal in magnitude. Cities with 20,000 or less population accounted for over two-thirds of the total growth increment, dominated by expansion in cities of the 5,000 to 20,000 population size range. The fact that the total net manufacturing employment increase among reporting communities was greater than the total net increase for the region as a whole provides evidence that manufacturing employment in many rural areas and in small villages not identified in the reporting system has continued to experience decline.

\section{EMERGING IMPLICATIONS FOR REGIONAL DEVELOPMENT}

\section{Prospects for Industrial Growth and Stability}

Continued manufacturing employment expansion appears to depend upon two critical elements. First, employment expansion in both indigenous firms and branch plants depends in large part on market expansion rather than enhanced competitive position. Second, the attraction of filtering-down branch plants will depend greatly upon the existence of adequate pools of low-wage, unskilled labor for industries which undertake less sophisticated fabrication, assembly and resource transformation operations.

Competition among regions and among individual communities for the localization of labor-oriented firms will continue to be a major characteristic of industrial attraction, especially until larger, more attractive labor pools are utilized. ${ }^{4}$ When local participation rates have peaked at low wage levels and substantial labor surpluses no longer exist, the attractiveness of a community for a large plant diminishes greatly where labor costs are a principal locational factor. 
Upgrading the quality of the labor force through various educational programs including vocational and technical programs represents somewhat of a paradox where firms are primarily interested in low cost, unskilled labor. As some researchers have suggested, such training may either provide the opportunity for outmigration and an ability to compete in metropolitan job markets, or a skill quite unrelated to employment opportunities within the region [9].

Available federal, state and local policy tools have generally been oriented more toward attracting relocating enterprises and branch plants than aiding indigenous ones. Primary emphasis has been placed on providing infrastructure for communities, generally in the form of industrial parks, sewer and utilities, and airports, etc. [20]. However, inasmuch as similar or identical publicly-supported infrastructure inducements are widely institutionalized and appear to be rather insignificant in the location decision, they represent no assurance that the sufficient conditions for industrial development will be met.

The prevalence of nonmetropolitan establishments characterized as "industry followers" su६gests rather, that for indigenous .enterprises, increased emphasis on the development of greater entrepreneurial, managerial and technical production skills seems appropriate. ${ }^{5}$ Furthermore, as existing markets become depleted at prevailing wage levels, smaller dispersed establishments may characterize those firms attracted to the region. These establishments are more likely to need management and technical assistance than are larger corporate organizations. Such a policy orientation may permit firms to operate more effectively in those later phases of the product cycle to which less sophisticated industrial enterprises are generally restricted.

Finally, the filtering-down process, in creating a substantial attraction for branch plants, may contribute to considerable instability in nonmetropolitan area economies. Evidence suggests that manufacturing branch plant establishments located in nonmetropolitan areas and oriented to fabrication and assembly are more adversely affected during periods of slumping product market demand than metropolitan plants in the same organization [15]. As product demand falls and inventories accumulate, production is curtailed, affecting fabrication and assembly plants as parent organizations "pull in" their activities to fewer plants. Where labor intensive branch plant operations have invested in limited fixed capital, there is considerable incentive to reduce or discontinue operations in such communities before doing so in main plants. When recovery occurs, changes in the organization's locational objectives and potential locational alternatives may induce management to choose a different area for resumption of production. Thus, the impacts of decline in the business cycle are likely to be more severe and recovery slower in nonmetropolitan branch plant operations. The recent closings of some regional plants as a result of the current national recession bear evidence of the severe economic consequences of dominant plant closings in nonmetropolitan communities. 


\section{Manufacturing Growth and Income Convergence}

Development policy at the federal and state levels has encouraged firms to locate on a non-selective basis, attempting to match the requirements of individual firms with appropriate community locations. On the surface, such a policy appears to have been successful, inasmuch as per capita incomes in the nonmetropolitan region have undergone a steady convergence with incomes in urban-industrial southeastern Wisconsin. ${ }^{6}$ Table 7 indicates that between the years 1962 and 1972 per capita incomes in the nonmetropolitan study area increased by $\$ 943$ in contrast to a $\$ 910$ per capita increase in the Southeast.

Traditional economic wisdom would generally attribute such nonmetropolitan-metropolitan income convergence to a more rapid increase in the labor force participation rate of the former area [1]. However, labor force participation data for this period indicate that despite a substantial nonmetropolitan increase, rates for southeastern Wisconsin rose slightly more rapidly. An analysis of income components in 1962 and 1972 indicates that increases in transfer payments ${ }^{7}$ accounted for over seventy percent of the positive contribution to narrowing the per capita income gap between the regions (Table 7).

Perhaps a more significant indication of the impacts of recent nonmetropolitan industrial expansion is found in the divergence of the labor and proprietor's component of personal income between the regions. While this divergence is partially explained by labor force participation levels, Table 8 shows that since the mid-1960s, during the period of more

\section{TABLE 7}

Increase in Regional Per Capita Income by Component, 1962 and 1972

\begin{tabular}{llccc}
\hline Component & NW & $\begin{array}{c}\text { Per Capita } \\
\text { Cersonal Income } \\
\text { Component 1962 }\end{array}$ & $\begin{array}{c}\text { Per Capita } \\
\text { Personal Income } \\
\text { Component 1972 }\end{array}$ & $\begin{array}{c}\text { Change } \\
\text { NW vs SE }\end{array}$ \\
$\begin{array}{l}\text { Labor and } \\
\begin{array}{l}\text { Proprietors } \\
\text { Income }\end{array}\end{array}$ & SE & 2060 & $\$ 2529$ & $\$-20$ \\
$\begin{array}{l}\text { Property } \\
\text { Income }\end{array}$ & NW & 201 & 3380 & +15 \\
$\begin{array}{l}\text { Transfer } \\
\text { Payments }\end{array}$ & SE & 320 & 512 & +38 \\
All & NW & 169 & 616 & \\
Components & SE & 162 & 477 & +33 \\
& NW & 1599 & 432 & +3518 \\
\hline
\end{tabular}

Source: Derived from data provided by the Bureau of Economic Analysis, U.S. Department of Commerce. 
TABLE 8

Manufacturing Payrolls per Employee by Region, 1963, 1967 and 1972

Wisconsin $=100$

\begin{tabular}{lrrr}
\hline & 1963 & 1967 & 1972 \\
\hline Northwest & 79.5 & 83.6 & 73.6 \\
Southeast & 104.5 & 104.0 & 108.5 \\
State & 100.0 & 100.0 & 100.0 \\
\hline
\end{tabular}

Source: U.S. Department of Commerce, Bureau of the Census, Census of Manufactures, 1963, 1967 and 1972 (Washington, D.C.: Government Printing Office)

rapid infusion of new firms into the nonmetropolitan region, manufacturing wage levels between the two areas began to diverge after a steady period of convergence. This pattern, of course, adversely affects the future prospects for income and developmental convergence between the two regions and hence, the nonmetropolitan region's ability to attract and hold population and supporting activities.

\section{Spatially-Selective Policies for Public Investment}

Over the past two decades the growth center concept has become an increasingly utilized strategy for regional economic development. The growth center strategy seeks to take advantage of decentralizing forces by attracting economic activities to moderately-sized urban centers where scale economies in the provision of community infrastructure and the positive benefits of urban agglomerations can generate sustained economic growth [7]. Such a strategy of concentrated investment has been considered for the development of nonmetropolitan Wisconsin selecting only three or four of the largest nonmetropolitan urban centers [3].

Yet, the above analysis of nonmetropolitan Wisconsin has shown that manufacturing employment was increasing most rapidly among cities with 20,000 or less population. In addition, other evidence indicates that the largest urban centers of the region are not experiencing as rapid a rate of population and employment growth (including manufacturing) as was occurring during much of the 1960s [21]. Using sectoral profiles of recent community growth, Erickson and Huddleston [5] examined growth patterns in communities one and two standard deviations above mean employment growth in various size categories. The growth of public sector and specialized services employment was most pronounced in those nonmetropolitan urban centers with more than 20,000 population; manufacturing employment growth was most notable among cities with 20,000 or less population; and services including retailing were a prominent factor in the growth of small cities and villages.

The selectivity of recent nonmetropolitan growth is best understood from a functional and hierarchical perspective. Public sector and specialized services employment depends upon service thresholds which general- 
ly make it most efficient or accessible to locate in areas of major population agglomerations. Alternatively, manufacturing establishments have found that production cost advantages arise from location in smaller nonmetropolitan cities. Finally, the trend toward greater household decentralization into villages has provided a limited rejuvenation for retailing and some other service activities within this type of settlement.

It is questionable whether a growth center policy which selects only the largest nonmetropolitan urban centers for designation as growth centers with appropriate concentration of public investment in those places will complement and enhance to the fullest extent what potentialities exist for continued industrial development and economic turnaround. A hierarchically-selective pattern of public investment would be most supportive of present trends and growth prospects in the region.

\section{CONCLUSIONS}

The demand for unskilled labor and the high level of dependence on general market expansion rather than efficiency improvements create some adverse effects associated with the growth of nonmetropolitan manufacturing. The dilemma of public policy which seeks to encourage industrial development in nonmetropolitan areas is apparent. As Lonsdale [11, p. 562] has suggested, "perhaps the most direct way to promote decentralization is to encourage lower wage rates in less-developed regions." Yet, the evidence indicates that while population and manufacturing decentralization is taking place, the divergence in wage rates and labor income will produce a widening disparity in income levels which can only be compensated for by increased transfers from state and federal governments.

There appears to be increasing national interest in problems of industrial agglomeration and the prospects of shifting the spatial location of industries to nonmetropolitan areas where environmental carrying capacities are deemed to be greater and the social costs of congestion smaller. In a recent book concerning population dispersal, Sundquist [17] argues that a national policy for the spatial distribution of industrial activities is vitally needed to attract industries into nonmetropolitan areas. The evidence, however, suggests that traditional public inducements such as infrastructure-building and tax incentives, and spatially-selective policies such as growth center strategies will need to be revamped. It appears that substantially higher government subsidies will be needed to significantly alter the locational patterns of industrial firms.

Thus, many questions remain unanswered concerning the wisdom of large-scale subsidies and public investments for industrial development in nonmetropolitan areas. Given the characteristics of the product cycle and nonmetropolitan attributes, it may be an inefficient allocation of resources to attempt to alter significantly locational patterns. Research may indicate that continued transfer payments are a more cost-effective 


\section{means of closing the income gap and dealing with distributional consid- erations.}

\section{FOOTNOTES}

1In recent years, development planning in Wisconsin has been focused on two distinct geographic areas with different development problems. An 18-county area which includes the major urban and industrial concentration of the state has been defined as the Southeast Region. The remaining 54 counties constitute the North/West Region. Only two counties form all or part of small Standard Metropolitan Statistical Areas within this latter region, and these have been removed from the analysis.

2The likelihood ratio ( $\lambda$ ) approximates closely the chi-square distribution in the form $-2 \log _{e} \lambda$ for large samples.

3 Similar research using a large sample has indicated that two-thirds of the plants surveyed were located within the corporate limits of towns in the South of the United States:
See [12].

4 One regional community's industrial association sponsors an Employment Center where more than 700 persons are currently registered seeking full or part-time work. This service provides firms with a useful indication of labor pool size and helps reduce recruitment time and costs.

5The importance of these skills is frequently overlooked, but has been stressed in the research of Chinitz [2] and George [6].

6The Southeast Region (previously defined) represents over two-thirds of the state's population and employment.

7Transfer payments generally consist of disbursements to persons for which no services are rendered currently, such as unemployment benefits, social security payments, veterans benefits, welfare and relief payments.

\section{REFERENCES}

1. Bowen, W. G. and T. A. Finegan, The Economics of Labor Force Participation (Princeton, N.J.: Princeton University Press, 1969).

2. Chinitz, B., "Appropriate Goals for Regional Economic Policy," Urban Studies, Vol. 3, No. 1, February 1966, pp. 1-7.

3. Deshpande, V. and R. Ross, "Potential Growth Areas of Northern and Western Wisconsin," Wisconsin Bureau of Planning and Budget, Madison, Wisconsin, June 1973.

4. Erickson, R. A., "The Filtering-Down Process: Industrial Location in a Nonmetropolitan Area," Professional Geographer, Vol. 28, No. 3, August 1976, pp. 254-260.

5. Erickson, R. A. and J. Huddleston, Small Community Growth, Wisconsin State Department of Administration, DOA-SPO-758(1), August 1975.

6. George, R., $A$ Leader and a Laggard: Manufacturing Industry in Nova Scotia, Quebec and Ontario (Toronto, Canada: University of Toronto Press, 1970).

7. Hansen, N. M., Intermediate-Size Cities as Growth Centers (New York, N.Y.: Praeger, 1971).

8. Hansen, N. M., The Future of Nonmetropolitan America: Studies in the Reversal of Rural and Small Town Population Decline (Lexington, Mass.: D. C. Heath and Company, 1973).

9. Hansen, N. M., Location Preferences, Migration and Regional Growth (New York, N.Y.: Praeger, 1973).

10. Hirsch, S., "The United States Electronics Industry in International Trade," National Institute Economic Review, No. 34, 1965, pp. 92-97.

11. Lonsdale, R. E., "Industrial Decentralization: An International Dilemma," International Geography 1972, Proceedings of the
International Geographical Union Congress, August 1972, pp. 560-562.

12. Lonsdale, R. E., and C. E. Browning, "Rural-Urban Locational Preferences of Southern Manufacturers," Annals of the Association of American Geographers, Vol. 61, No. 2, June 1971, pp. 255-268.

13. Mansfield, E., "Entry, Gibrat's Law, Innovation and the Growth of Firms," American Economic Review, Vol. 52, No. 5, December 1962, pp. 1023-1051.

14. Salter, W. E., Productivity and Technical Change (Cambridge, England: Cambridge University Press, 1960).

15. Steed, G. P. F., "Forms of Corporate Environmental Adaptation," Tijdschrift voor Economische en Sociale Geografie, Vol. 62, No. 2, March/April 1971, pp. 90-94.

16. Summers, G., S. Evans, F. Clemente, E. Beck, Jr. and J. Minkoff, Industrial Invasion of Nonmetropolitan America (New York, N.Y.: Praeger, 1976).

17. Sundquist, J. L., Dispersing Population (Washington, D. C.: The Brookings Institution, 1975)

18. Thompson, W. R., "The Economic Base of Urban Problems," in N. W. Chamberlain (ed.), Contemporary Economic Issues (Homewood, Ill.: Richard D. Irwin, 1969).

19. U. S. Dept. of Commerce, Economic Development Administration, Plant Site Characteristics 1970 (Washington, D. C.: Government Printing Office, 1973).

20. Upper Great Lakes Regional Commission, Development Strategies: Upper Great Lakes Region, Annual Report, January 1969.

21. Wisconsin State Dept. of Administration, "Population Trends in Wisconsin, 1970. 1973," Document No. PE-A-BK-080574, August 1974. 